\title{
Nauczyciel (a)medialny? Kompetencje medialne nauczycieli i ich wykorzystanie w nauczaniu zdalnym
}

\section{(A)media Teacher? Teachers' Media Skills}

in Distance Learning

\begin{abstract}
ABSTRAKT
W zmieniającym się świecie i w bezprecedensowych sytuacjach nauczyciele staja przed nowymi wyzwaniami. Takim wyzwaniem stała się obecnie konieczność podjęcia nauczania zdalnego. Wielu z nich odczuwało z tego powodu presię oraz dystans wobec wykorzystywania narzędzi cyfrowych. Jedyna droga było jednak stawienie czoła nieznanym obszarom oraz dostosowanie się do wymagań cyfrowego świata i cyfrowych tubylców-uczniów.

Skuteczne prowadzenie nauczania na odległość, w atrakcyjnych dla uczniów formach, oznacza konieczność stałego doskonalenia własnych kompetencji tak, by chociaż w pewnym stopniu nadażyć za dynamikq zmian rzeczywistości.

Wiosna 2020 roku pandemia COVID-19 wymusiła zmiany w każdej dziedzinie ludzkiej działalności, odciskając piętno także na działaniach edukacyjnych. Mimo problemów zwiqzanych z zawieszeniem zajęć w ramach tradycyjnego nauczania, wiele przeszkód udało się nauczycielom pokonać. Stan ten uwydatnił jednak sporo
\end{abstract}

SLOWA KLUCZOWE nauczanie zdalne, e-learning, nowoczesne technologie, media cyfrowe, kompetencje medialne nauczycieli, pandemia

\section{KEYWORDS}

distant learning, e-learning, new technologies, digital media, pandemic, teachers' media competences

SPI Vol. 23, 2020/4 ISSN 2450-5358 e-ISSN 2450-5366 DOI: 10.12775/SPI.2020.4.004

Nadestano: 30.06 .2020 Zaakceptowano: 10.10.2020 Artykuły i rozprawy 
edukacyjnych słabości, a biegłe stosowanie nowoczesnych technologii w procesie dydaktycznym okazało się pięta achillesowq wielu z nich. Pewne jest jednak, że niezależnie od tego jak proces edukacyjny będzie zorganizowany w przyszłości, umiejętne prowadzenie nauczania z wykorzystaniem komputera $\mathrm{i}$ Internetu stało się jednym z niezbędnych wymogów stawianych nauczycielom. Pewne jest też, że w wyniku konieczności szybkiego dostosowania się do zmian, mimo szeregu negatywnych konsekwencii, wielu nauczycieli przełamało lęk przed stosowaniem narzędzi cyfrowych i z powodzeniem będzie je nadal wykorzystywać w swojej pracy.

\section{ABSTRACT}

In today's changing world and situations without precedent teachers need to face new challenges. One of them was necessity to start distance learning. A lot of teachers felt pressure and were afraid of using new technologies in education but the only one solution was to adapt to demands of a digital world and students - digital natives.

Effective distance learning with methods which are attractive for students means necessity of constant improving teachers' skills and qualifications to cope with dynamic reality.

In spring 2020 COVID-19 pandemic imposed changes in all areas of human activities, in education as well. Despite problems with the lack of normal classes, teachers managed to overcome a lot of obstacles. This extraordinary situation showed a lot of difficulties with using digital media among many teachers but we can be sure that, no matter what way the educational process will be organized in future, skills related with using new technologies in teaching are now one of the basic demands for teachers. In spite of many negative consequences of e-learning in new conditions, lots of teachers confronted their fear of using new media and for sure will make use of them in their future work.

\section{Wprowadzenie}

Zasadne wobec dzisiejszej rzeczywistości jest użycie określenia „płynna nowoczesność”, sformułowanego przez Zygmunta Baumana. Według tego wybitnego socjologa i filozofa, teraźniejszość cechuje permanentna zmienność, 
[...] dzisiaj tracimy zainteresowanie tym, co jeszcze wczoraj nas przyciągało, by już jutro zobojętnieć na to, co ekscytuje nas dzisiaj. [...] Nasz świat, świat płynnej nowoczesności, nieustannie nas zaskakuje: to, co dziś wydaje się pewne i na właściwym miejscu, już jutro może się okazać żałosną pomyłką (Bauman 2011: 5-7).

Każde pokolenie żyje w nieco innej rzeczywistości społeczno-kulturowej, technicznej i cywilizacyjnej, które przybierają nie raz postać kryzysów, zagrożeń czy bezradności w osiąganiu celów. Jednostka stawiana jest niejednokrotnie w nieznanych wcześniej sytuacjach, wymaga się od niej stawiania czoła nowym problemom, dokonywania wyborów, z jakimi wcześniejsze pokolenia nie miały do czynienia (Włoch 2010: 79).

Tak też stało się wiosną 2020 roku, kiedy to świat stanął przed wyjątkowo trudnym wyzwaniem - pandemią COVID-19. Yuval Noah Harari (2015) stwierdza, że w ciągu ostatnich dziesięcioleci ludzkości udało się poskromić jeden z trzech głównych problemów, z którym od zarania dziejów ludzie nie potrafili sobie poradzić - zarazę (pozostałe dwa to według autora wojna i głód). Patrząc jednak z perspektywy początku roku 2020, można zadać sobie pytanie - czy na pewno? Mimo że różne są poglądy i statystyki na temat skali epidemii, niezaprzeczalny jest fakt, że stan ten wywarł ogromny wpływ na wszystkie dziedziny ludzkiej działalności, między innymi na oświatę, w tym na sposób prowadzenia procesu edukacyjnego. Tradycyjne, stacjonarne nauczenie zostało wstrzymane, a nauczyciele, uczniowie i rodzice stanęli w obliczu egzaminu, z jakim wcześniej nie mieli okazji ani konieczności się mierzyć - nauczaniem zdalnym.

W niniejszym artykule podjęto rozważania dotyczące poziomu kompetencji nauczycieli w zakresie prowadzenia lekcji zdalnie, a także próbę krytycznego spojrzenia na ich motywację i zaangażowanie w proces ciągłego rozwoju i doskonalenia umiejętności w zakresie wykorzystania nowoczesnych technologii.

\section{Nauczanie zdalne - fakty}

Według zapisów raportu z badań przeprowadzonych przez Centrum Cyfrowe (Centrum Cyfrowe 2020) w kwietniu 2020 roku na grupie prawie 1000 polskich nauczycieli, przed rozpoczęciem pandemii 85,4\% badanych nauczycieli nie miało żadnych wcześniejszych 
doświadczeń z nauczaniem zdalnym (mimo to $48 \%$ badanych potwierdziło brak trudności z obsługą narzędzi cyfrowych). Jedynie $9 \%$ badanych nauczycieli przyznało, że główną trudnością w prowadzeniu nauczania zdalnego są problemy z umiejętnością obsługi narzędzi cyfrowych, a nawet jeśli ich poznawanie wymaga dodatkowego nakładu czasu i pracy - nie jest to dla nich barierą. Niestety tylko niecałe $63 \%$ badanych nauczycieli klas IV-VIII szkoły podstawowej w ramach nauczania zdalnego zdecydowało się prowadzić lekcje na żywo, $26 \%$ skupiło się przesyłaniu uczniom filmów z prowadzonymi przez siebie lekcjami. Większość nauczycieli biorących udział w badaniu stosowała, mimo konsekwencji czasowych, więcej niż jedną metodę nauczania zdalnego. Wielu nauczycieli nauczanie zdalne pojmowało jednak w tamtym okresie jako wysyłanie uczniom linków do ogólnodostępnych lekcji i materiałów w Internecie czy informacji z zadaniami i materiałem do „przerobienia”. Według raportu, nauczyciele doświadczali dużego napięcia związanego ze zdalnym nauczaniem. Na poziom stresu wpływała także konieczność przyjmowania na siebie frustracji uczniów i rodziców, a dodatkowo nauczyciele czuli się osamotnieni, negatywnie oceniani, wystawieni na trudne warunki, bez żadnego instytucjonalnego wsparcia.

Wśród nauczycieli, uczniów oraz ich rodziców widoczne były symptomy nadużywania mediów cyfrowych. Przemęczenie, przeładowanie informacjami, niechęć do korzystania z komputera i Internetu oraz rozdrażnienie z powodu zwiększonej częstotliwości korzystania $z$ technologii informacyjno-komunikacyjnych to najczęściej opisywane przez te trzy grupy objawy zmęczenia cyfrowego (Polskie Towarzystwa Edukacji Medialnej, Fundacja Dbam o Mój Zasięg, Fundacja Orange 2020).

Portal Librus przeprowadził podobne badania dwukrotnie w kwietniu oraz czerwcu 2020 roku. Dzięki temu możliwe było zaobserwowanie zmian $\mathrm{w}$ sposobach prowadzenia nauczania zdalnego. $Z$ badań wynika, że wraz z upływem czasu nauczyciele zaczęli częściej korzystać z platform do prowadzenia wideolekcji i chętniej stosowali dostępne narzędzia cyfrowe. Niewątpliwie wpłynęło to na większą atrakcyjność zajęć oraz na samodzielność dzieci, a tym samym odciążenie rodziców (Librus 2020).

Wyjątkowa sytuacja, która nastała w pierwszej połowie $2020 \mathrm{roku}$, przyniosła też inne pozytywne skutki. Paradoksalnie - nauczanie na 
odległość zmniejszyło dystans nauczyciel-uczeń. Wielu uczniów (ale i nauczycieli) w tej formie edukacji odnalazło sposób na otwarcie się na siebie nawzajem i lepsze poznanie partnera w procesie edukacyjnym. Dodatkowo relacje między nauczycielami w wielu przypadkach uległy poprawie, bo nauczycielskie inicjatywy służące pomocy tym, którzy z odnalezieniem się w cyfrowym świecie mają problemy, posłużyły lepszej współpracy i zacieśnieniu więzi (Pacewicz 2020).

Przestrzeń edukacyjna jest niewątpliwie pojęciem, które stale się rozwija, zagarniając coraz większe obszary, wśród nich także przestrzeń wirtualną, która staje się coraz bardziej popularną płaszczyzną organizacji procesu edukacyjnego. Ośrodki elektronicznego przekazu - zwłaszcza sieci internetowe - stworzyły nowe możliwości wzajemnych oddziaływań i w dobie obecnej ich wykorzystanie zatacza (albo też musi zataczać) coraz szersze kręgi (Myrdzik 2015: 13).

To, że kompetencje cyfrowe nauczycieli uległy znaczącej poprawie, nie ulega wątpliwości. Oczywiście nowy tryb pracy miał też negatywne konsekwencje, jeśli jednak się zastanowić nad poziomem kompetencji medialnych współczesnego nauczyciela, bilans z pewnością jest dodatni.

\section{Nauczyciel i potrzeba ciagłego uczenia się}

Codzienna dynamika zmian wymaga, aby zarówno nauczyciele, jak i uczniowie nieprzerwanie się uczyli. Uczenie się natomiast, jako wielopoziomowa i złożona aktywność, oparte jest na zdolnościach, umiejętnościach i procesach takich jak: myślenie, obserwacja, zapamiętywanie, uwaga, koncentracja, wyobraźnia (Popławska, Aniskievich 2017: 249).

Nie wystarczy już więc posiadanie przez nauczyciela wiedzy kierunkowej z danej dziedziny. Życie w warunkach intensywnych zmian społeczno-gospodarczych oraz z nowymi problemami zmusza go do ciągłego kształcenia, na przykład w zakresie technologii informatycznej i edukacji medialnej (także ekologii, polityki, ekonomii, edukacji obywatelskiej, zdrowotnej), po to, by wyjaśniać młodym ludziom trudności i zawiłe procesy, z którymi zetknęli się lub z którymi będą mieć do czynienia w przyszłości (Szot 2009: 305).

W związku $z$ tym istotne jest, by nauczyciel posiadał zestaw cech osobowościowych, które wyrażając się w praktycznym działaniu, są 
konieczne do rozwiązywania zadań z wykorzystaniem instrumentów cyfrowych. W grupie niezbędnych jego kompetencji znajduje się także umiejętność refleksyjnego podejścia do własnych wiadomości i umiejętności z zakresu stosowania metod oraz narzędzi technologii informacyjno-komunikacyjnych (Baron-Polańczyk 2012: 178). Media stały się ważnym środowiskiem edukacyjnym dla współczesnego ucznia, a sam nauczyciel musi posiadać kompetencje medialne dla własnego rozwoju oraz organizowania procesu dydaktycznego. Inne są dzisiaj oczekiwania uczniów wobec nauczycieli, którzy poza tradycyjnymi kompetencjami muszą uzupełniać także swoje kwalifikacje i kompetencje medialne, aby uczenie się zarówno nauczycieli, jak i uczniów (także te przygotowujące ich do uczenia się przez całe życie) było efektywne (Wenta 2007: 214-216).

Dzisiejsza edukacja to już nie 45-minutowa lekcja, lecz proces stałego doskonalenia się przez 24 godziny na dobę, 7 dni w tygodniu. Uczniowie uczą się wszędzie i cały czas. Nowe technologie edukacyjne wspierają ich w tych procesach. Nauczyciele mogą korzystać z zasobów informacji dostępnych na całym świecie, współpracować online, kreować własne zasoby edukacyjne, odkrywać, budować, rozbudowywać i uzupełniać swoje kompetencje. Cyfrowe lekcje to możliwości dużo większe niż tylko wykorzystywanie odpowiednich narzędzi. To również korzystanie z odpowiednich metod pracy oraz planowanie wartościowej edukacji online. Sposób jej realizowania powinien być zgodny z celami dydaktycznymi stawianymi przed danymi zajęciami, a przede wszystkim - odpowiadać potrzebom, oczekiwaniom i możliwościom młodych uczestników tego procesu. Zajęcia cyfrowe powinny też podlegać monitorowaniu i ewaluacji, tak by na bieżąco badać ich rzeczywistą jakość oraz weryfikować, czy wybrane metody przyczyniają się do powstania wartości dodanej. Jest to materia, którą można i warto modyfikować w tracie realizacji, tak aby optymalnie odpowiadała potrzebom edukacyjnym (Plebańska 2020: 37-42).

Jakość interakcji pomiędzy nauczycielem i uczniem to ważna determinanta efektywności procesu dydaktycznego. W równym stopniu odnosi się to także do nauczania na odległość. Komunikowanie się za pośrednictwem sieci komputerowych dokonuje się przeważnie na płaszczyźnie słownej (czy też tekstowej), ale partnerzy procesu edukacyjnego mogą widzieć się wzajemnie i reagować na swoje 
zachowania. Powstaje wtedy sytuacja zbliżona do tej, jaka występuje w normalnych, szkolnych interakcjach. W tym przypadku nauczyciel musi jednak brać pod uwagę szereg prawidłowości psychologicznych procesów komunikowania się, percepcji interpersonalnej i postrzegania własnej osoby (Hankała 2005: 17-27). Nauczanie online nie musi więc znacząco się różnić od tradycyjnego, wymaga natomiast umiejętności radzenia sobie $\mathrm{z}$ nowoczesnymi technologiami i refleksyjnego podejścia.

Nauczyciel staje się projektantem procesu edukacyjnego. Odejście od trybu podawczego i przyjęcie roli przewodnika po świecie informacji, z których warto budować wiedzę - to dzisiejsze wyzwanie, wymuszone przez nietypową i niespotykaną wcześniej sytuację. To od doboru treści, sposobu ich prezentacji, metodyki wprowadzania, tempa pracy, stworzenia przestrzeni dla samodzielności i twórczości uczniów oraz jej prezentowania we wspólnych projektach zależy zaangażowanie uczniów, wyzwolenie ich kreatywności i wytworzenie pozytywnego nastawienia oraz mody na uczenie się (Ścibor 2020: 63). Nieprzewidywalność dzisiejszego świata i zachodzących w nim procesów wymaga więc od nauczyciela określonych kompetencji w celu sprostania wyzwaniom rzeczywistości. Są to kompetencje prakseologiczne, komunikacyjne, współdziałania, informatyczne, moralne oraz kreatywne. Powinny one podlegać nieustannej ewolucji i ciągłym korektom, a dążenie do samodoskonalenia stanowić winno kolejną z cech pedagoga (Szot 2009: 304). Poważne podejście do uczenia się przez całe życie wiąże się z odpowiedzialnością za ciągłe rozwijanie własnych umiejętności, zdolności i wiedzy, bo uczenie się nie jest domeną tylko dzieci i młodzieży, ale zadaniem wszystkich, również dorosłych (Holtkamp 2011: 173).

W kwestii stałego podnoszenia nauczycielskich kwalifikacji należy się przyjrzeć także zapisom Rozporządzenia Ministra $\mathrm{Na}$ uki i Szkolnictwa Wyższego (Rozporządzenie... 2019) w sprawie standardu kształcenia przygotowującego do wykonywania zawodu nauczyciela. Określa ono, jakie wiadomości i umiejętności powinien posiadać nauczyciel. Znaleźć tu także można wiele wytycznych odnośnie do nauczycielskich kompetencji w zakresie wiedzy i umiejętności dotyczących wykorzystywania nowoczesnych technologii, a mianowicie: znajomość i rozumienie metod „nauczania i doboru efektywnych środków dydaktycznych, w tym zasobów 
internetowych, wspomagających nauczanie przedmiotu lub prowadzenie zajęć, z uwzględnieniem zróżnicowanych potrzeb edukacyjnych uczniów"; adekwatne dobieranie, tworzenie i dostosowywanie do zróżnicowanych potrzeb uczniów materiałów i środków, w tym z zakresu technologii informacyjno-komunikacyjnej; samodzielne rozwijanie wiedzy i umiejętności pedagogicznych z wykorzystaniem różnych źródeł, w tym obcojęzycznych oraz technologii.

Zgodnie z omawianym Rozporządzeniem, absolwent kierunków związanych z nauczaniem wszystkich przedmiotów powinien znać i rozumieć:

[...] kompetencje merytoryczne, dydaktyczne i wychowawcze nauczyciela, $\mathrm{w}$ tym potrzebę zawodowego rozwoju, także $\mathrm{z}$ wykorzystaniem technologii informacyjno-komunikacyjnej, $[\ldots]$ sposoby organizowania przestrzeni klasy szkolnej, z uwzględnieniem zasad projektowania uniwersalnego: środki dydaktyczne (podręczniki i pakiety edukacyjne), pomoce dydaktyczne - dobór i wykorzystanie zasobów edukacyjnych, w tym elektronicznych i obcojęzycznych, edukacyjne zastosowania mediów i technologii informacyjno-komunikacyjnej; powinien wykazywać się myśleniem komputacyjnym w rozwiązywaniu problemów w zakresie nauczanego przedmiotu lub prowadzonych zajęć (Rozporządzenie... 2019: 17, 18).

Według tego Rozporządzenie każdy nauczyciel powinien także odczuwać „potrzebę wyszukiwania, adaptacji i tworzenia elektronicznych zasobów edukacyjnych i projektowania multimediów" (Rozporządzenie... 2019: 18), znać metody kształcenia w odniesieniu do nauczanego przedmiotu lub prowadzonych zajęć, a także dostrzegać „Znaczenie kształtowania postawy odpowiedzialnego i krytycznego wykorzystywania mediów cyfrowych oraz poszanowania praw własności intelektualnej” (Rozporządzenie... 2019: 18).

W zakresie umiejętności absolwent powinien umieć dobierać „metody pracy klasy oraz środki dydaktyczne, w tym z zakresu technologii informacyjno-komunikacyjnej, aktywizujące uczniów i uwzględniające ich zróżnicowane potrzeby edukacyjne" (Rozporządzenie... 2019: 19), a w zakresie kompetencji społecznych „absolwent jest gotów do promowania odpowiedzialnego i krytycznego wykorzystywania mediów cyfrowych oraz poszanowania praw własności intelektualnej" (Rozporządzenie... 2019: 20).

W odniesieniu do edukacji wczesnoszkolnej i przedszkolnej nauczyciele powinni „skutecznie porozumiewać się z różnymi 
odbiorcami, w tym z dziećmi lub uczniami, rodzicami lub opiekunami oraz specjalistami, z wykorzystaniem nowoczesnych rozwiązań technologicznych" (Rozporządzenie... 2019: 37).

Rozporządzenie zaznacza także istotną rolę technologii informacyjno-komunikacyjnych w pracy nauczycieli logopedów, terapeutów z zakresu wczesnego wspomagania rozwoju dziecka, nauczycieli-terapeutów pracujących z dziećmi przewlekle chorymi, z niepełnosprawnościami czy zaburzeniami ze spektrum autyzmu.

Zgodnie z Rozporządzeniem Ministra Edukacji Narodowej w sprawie uzyskiwania stopni awansu zawodowego przez nauczycieli, zarówno nauczyciele kontaktowi, mianowani jak i dyplomowani powinni posiadać „umiejętność korzystania w pracy, zwłaszcza w trakcie prowadzonych zajęć, z narzędzi multimedialnych i informatycznych” (Rozporządzenie... 2018: 3). Jednym z wymagań stawianych nauczycielom podczas egzaminu na kolejne stopnie awansu zawodowego jest wykonanie zadania $z$ użyciem narzędzi multimedialnych. Ponadto warunkiem uzyskania stopnia nauczyciela dyplomowanego jest podjęcie działań doskonalących warsztat pracy, w tym umiejętności stosowania technologii informacyjnej i komunikacyjnej.

Trzeba obiektywnie przyznać, że po zapoznaniu się z tymi podstawowymi aktami prawnymi, odnoszącymi się do fundamentalnych wymagań względem pracowników pedagogicznych, każda osoba wykonująca lub planująca wykonywać zawód nauczyciela powinna być świadoma stawianych przed nią wymagań z zakresu stosowania w procesie edukacyjnym nowoczesnych rozwiązań cyfrowych i umieć z powodzeniem je wykorzystywać. Czy tak jest? $\mathrm{Na}$ to pytanie niech każdy z czytelników spróbuje odpowiedzieć samodzielnie.

\section{Wykorzystanie nowoczesnych technologii w edukacii}

Maciej Tanaś proponuje, by współczesne

[...] media cyfrowe sprowadzać do następujących funkcji: narzędzi komunikacji społecznej, narzędzi nauczyciela i ucznia w procesach kształcenia i samokształcenia, a także nowej organizacji kształcenia zwanej kształceniem zdalnym; organizatora czasu wolnego człowieka, przestrzeni jego aktywności poznawczej, twórczej, ludycznej i społecznej; narzędzi pracy i jej pola (Tanaś 2015: 14). 
Wykorzystanie komputerów i sieci informatycznych w edukacji, jeśli tylko odpowiednio prowadzone, zgodne jest z zasadami komplementarności metod i różnicowania środków dydaktycznych. Blended learning - harmonijne i komplementarne stosowanie tradycyjnych metod nauczania w połączeniu $\mathrm{z}$ wykorzystaniem środków informatycznych zyskuje coraz więcej sympatyków. Sieć pozwala pokonać przestrzeń i czas, pozwala na prowadzenie dialogu w czasie rzeczywistym, a dialog ten może być prowadzony indywidualnie lub grupowo, w postaci pisemnej, graficznej, słownej, muzycznej i wizualnej (Tanaś 2005: 36-39). Trzeba pamiętać jednak o tym, że nauczanie zdalne to nie korzystanie z książek (elektronicznych lub drukowanych) czy przesyłanie materiałów pocztą elektroniczną. Nauczanie z wykorzystaniem technologii cyfrowej może przynieść wiele korzyści dla obu stron: zarówno uczniowie, jak i nauczyciele będą mieli np. dostęp do ciekawych materiałów, będzie możliwa większa indywidualizacja nauczania (Mischke 2005: 46-51).

W wieku XXI dostęp do informacji kształtowany jest przez dynamiczne zmiany technologiczne, a rozwój technik cyfrowych w szybkim tempie przeobraża rzeczywistość współczesnego człowieka. Wzrost ogólnodostępnych zasobów w Internecie oraz rodzaj relacji nawiązywanych za pośrednictwem sieci implikują istotne zmiany $\mathrm{w}$ postrzeganiu roli nauczyciela w procesie edukacyjnym (Królikiewicz, Pulak 2020: 26). Rozwój sieci globalnej pozwolił na interakcję użytkownika $z$ aplikacją internetową, serwisem internetowym czy innym użytkownikiem sieci. Technologia umożliwiła współtworzenie treści, dynamiczne jej przetwarzanie oraz dzielenie się zasobami informacji. Stworzone w tym celu aplikacje i nowe usługi sieciowe otworzyły nowe możliwości, które następnie zaowocowały powstaniem nowych narzędzi, a co za tym idzie - nowych technik ich wykorzystania. Pojawiły się narzędzia pozwalające na zespołową pracę zdalną $\mathrm{w}$ czasie rzeczywistym. Uproszczone mechanizmy ułatwiające publikację treści w sieci czy systemy komentarzy pozwoliły na łatwiejszą interakcję z odbiorcami publikowanych treści. W kolejnych latach (r)ewolucji Internetu obserwowano rosnący udział aplikacji, do których dostęp uzyskiwany jest za pomocą przeglądarek internetowych (tzw. webowych), oraz dynamiczny wzrost zainteresowania różnego rodzaju serwisami społecznościowymi. Współczesny nauczyciel ma do wyboru wiele narzędzi informatycznych wspomagających jego 
pracę w zakresie kształcenia i samokształcenia oraz organizacji własnej pracy (blogi, serwisy społecznościowe, platformy e-learningowe, narzędzia dedykowane edukacji). Metody oparte na przekazie audio i wideo, należące do metod eksponujących, mogą stanowić wstęp do użycia kolejnych metod pracy z uczniami. Dzisiejsze rozwiązania informatyczne dają szansę na wygodne, ale i nieograniczone korzystanie z multimediów zarówno lokalnie, jak i poprzez tzw. przekaz strumieniowy. W tym przypadku kompetencje nauczyciela, wychodząc poza umiejętność publikacji materiału na odpowiedniej platformie, np. YouTube, kierują się w stronę umiejętności pozwalających na nagrywanie i montaż materiału audiowizualnego, np. w postaci podcastów (w tym screencastów, audio i videocastów). Wszystkie te rozwiązania mają wspólny cel, a jest nim zapewnienie kompleksowego, atrakcyjnego i uniwersalnego środowiska, dającego możliwość nauki w atrakcyjnej i nowoczesnej formie, niezależnie od tego, czy wykorzystywane są w stacjonarnym procesie edukacyjnym czy w nauczaniu zdalnym. W ślad za kompetencjami technologicznymi - związanymi ze znajomością narzędzi takich jak: przeglądarka internetowa, dedykowane platformy e-learningowe czy szeroka gama innych specjalistycznych aplikacji - powinny iść kompetencje dydaktyczne, tj. dotyczące uczenia się i nauczania metodami wykorzystującymi współczesny warsztat pracy nauczyciela oparty na nowoczesnych rozwiązaniach technologicznych. Wydaje się to oczywiste ze względu na konieczność wzbogacenia i zróżnicowania przekazywanych treści oraz oczekiwanie uatrakcyjnienia tradycyjnych form przekazu (Muchacki 2016: 434-436).

Wśród typowych zastosowań urządzeń elektronicznych w procesie edukacyjnym możemy wyróżnić:

- uatrakcyjnienie metody podawczej poprzez np. wykorzystanie przez nauczyciela prezentacji multimedialnej, filmów, zdjęć, animacji,

- samodzielne wyszukiwanie informacji przez uczniów,

- quizy i ćwiczenia służące utrwalaniu materiału,

- wykorzystanie narzędzi komunikacji do wykonywania wspólnych zadań z innymi szkołami (także zagranicznymi),

- wirtualne eksperymenty, które w standardowych warunkach szkolnych nie są możliwe do przeprowadzenia, 
- pracę grupową, podczas której każdy z uczestników wykonuje fragment obszernego zadania,

- poznawanie otaczającego świata, np. „wirtualne wycieczki” w kosmos czy do wnętrza ludzkiego organizmu,

- samodzielne przygotowanie przez uczniów prezentacji, eksperymentów, nagrań itp. (Wronka 2018: 343-344).

Wykorzystanie multimediów już na etapie wczesnoszkolnym pozwala na łączenie nauki z zabawą, a takie połączenie wpływa na większą atrakcyjność zajęć - zabawa na początkowym etapie kształcenia spełnia ważną funkcję, jest też pożądana przez wychowanków. Stosowanie multimediów przyczynia się również do zwiększenia motywacji do nauki, kształtuje postawy proedukacyjne. Ponadto umożliwia indywidualizację kształcenia i upodmiotawia uczniów, a obydwie te cechy są aktualnie wysoko cenione w procesie edukacyjnym (Rygatło 2015: 30). Pokolenie dzisiejszych uczniów wymaga wykorzystywania w edukacji technologii, które są im znane, służą codziennej komunikacji czy poznawaniu świata. Postulowane zmiany wymagają jednak zgody nauczycieli na przekazanie przynajmniej części odpowiedzialności za kształcenie samym uczącym się, a jednocześnie aprobaty uczniów pokolenia sieci na przyjęcie tej odpowiedzialności (Morbitzer 2011: 26-33). Niezbędną umiejętnością nauczyciela jest więc skuteczne nawiązywanie dialogu z uczniem, ale by było to możliwe, musi on posiadać kompetencje $\mathrm{w}$ zakresie wdrażania $\mathrm{w}$ proces dydaktyczny nowoczesnych rozwiązań (Banasik 2017: 224).

\section{Nauczyciel i media - codzienność czy dystans?}

Zawód nauczyciela jest szczególnym rodzajem zawodu, gdyż jego podstawowe założenia opierają się na budowaniu relacji z ludźmi oraz umiejętności pracy zespołowej. Nauczyciel niejednokrotnie wykonuje swoją pracę w stanie podwyższonego napięcia, wytężonej uwagi i dużej aktywności. Na poziom stresu mają również wpływ czynniki takie jak: poczucie odpowiedzialności, presja czasu, niewłaściwa organizacja pracy, duże, nakładające się na siebie i często sprzeczne wymagania oraz oczekiwania kilku grup społecznych. W polskich warunkach dochodzą także czynniki wynikające $\mathrm{z}$ sytuacji społeczno-politycznej oraz gospodarczej, a mianowicie niskie 
zarobki, niepewność zatrudnienia oraz przybierające na sile niedocenianie zawodu nauczyciela (Zadworna-Cieślak, Zbonikowski 2016: 440-441).

W opisie sylwetki nauczyciela na miarę dzisiejszych czasów zawarte są postulaty, by był on wyemancypowanym intelektualistą, wprawnym w działaniu praktykiem i pełnym pasji profesjonalistą. Równocześnie powinien to być człowiek troskliwy, dbający o właściwy rozwój swoich wychowanków. Wskazane jest, by posiadał szerokie horyzonty, był otwarty na zmiany, miał bogatą wiedzę i umiejętność działania w różnych sytuacjach (Kobyłecka 2010: 105).

Nauczyciele są świadomi, że cyfrowy świat stanowi strefę szerokiego zasięgu i nieograniczonych możliwości. Dostrzegając negatywne skutki, jakie niesie dla uczniów wirtualna rzeczywistość (niepożądane treści i kontakty, hejt, plagiat zasobów sieciowych, pasywność użytkownika, bezrefleksyjne przyjmowanie niezweryfikowanych informacji), jednocześnie doceniają oni możliwości powszechnego dostępu do informacji, percepcji miejsc i zjawisk na co dzień niedostępnych, zdając sobie sprawę z potencjału przestrzeni wirtualnej (Krzyżanowska 2018: 213).

Wydaje się jednak, że aktualnie mówić można o asymetrii kompetencyjnej uczniów i nauczycieli.

Przewagi tych pierwszych w zakresie umiejętności korzystania ze współczesnej techniki nie sposób kwestionować, podobnie jak dziedzinowych, pedagogicznych i psychologicznych kwalifikacji nauczycieli. Gdy młodzi ludzie bywają nauczycielami dorosłych - choćby w zakresie obsługi podłączonego do sieci komputera - mówimy o zjawisku inwersji pedagogicznej (Mead 2000: 86).

Coraz bardziej kreatywni, mobilni i otwarci na nowości technologiczne uczniowie wydają się lepiej funkcjonować w świecie online niż offline, bo pochłaniają w bardzo szybkim tempie umiejętności pozwalające im na wykorzystanie nowych mediów. Zazwyczaj wyprzedzają w tym działaniu swoich nauczycieli (Huk 2019: 37). Mądrzy dorośli imigranci powinni jednak zaakceptować fakt, że nie znają swojego i swoich dzieci czy wychowanków świata oraz wykorzystać ich, by pomogli im się go uczyć i zintegrować. Nie tak mądrzy (albo też - nie tak elastyczni) imigranci w tej materii, także nauczyciele, będą marnować swój czas na rozpamiętywanie, jak dobrze było kiedyś (Prensky 2001: 3). 
Współcześni uczniowie określani są często mianem cyfrowych tubylców, gdyż wzrastali w przestrzeni multimedialnej, w wyniku czego cyfrowe technologie stanowią dla nich naturalne środowisko, w którym poruszają się bez większych trudności (Prensky 2001: 1-6). Cyfrowi tubylcy należą do pokolenia kultury obrazu, podczas gdy cyfrowi imigranci - osoby wychowane na książce drukowanej, które nie wzrastały w świecie wszechobecnych cyfrowych technologii i które muszą zdobywać wiedzę i umiejętności z zakresu stosowania technologii informacyjno-komunikacyjnych - przedkładają tekst nad obraz i dźwięk (Morbitzer 2012: 138). Tubylcy z cyfrowego świata szybciej oceniają informacje i podejmują decyzje; preferują wielozadaniowość; oczekują szybkich zmian oraz szybkich efektów; mają bardzo dobrą koordynację wzrokowo-ruchową, a dzięki temu potrafią dostrzegać więcej szczegółów; są otwarci na innowacje (Rygałło 2015: 30). Jednocześnie pojawiają się u nich trudności z właściwą interpretacją zapamiętywanych informacji, co jest niezbędnym procesem myślowym skutkującym budowaniem wiedzy. Miewają także problemy z myśleniem kreatywnym, formułowaniem wniosków czy uogólnień i nie są to różnice międzypokoleniowe, ale zmiany w funkcjonowaniu mózgu, które powodują, że mamy do czynienia z uczniem zupełnie odmiennym niż przed laty (Morbitzer 2011: 26). Manfred Spitzer autor wielu publikacji na temat funkcjonowania mózgu ludzi wykorzystujących cyfrowe media - twierdzi, że w związku z nadmiernym kontaktem $z$ mediami przedstawiciele pokolenia cyfrowych tubylców rzadziej używają swoich mózgów, mają mniejszy potencjał umysłowy oraz ograniczone zdolności kognitywne (Spitzer 2013: 280). Jak więc pogodzić te dwa odmienne sposoby postrzegania, funkcjonowania, myślenia czy uczenia się? Często pedagogiczna krytyka mediów oparta na założeniu, że nie są one w stanie zastąpić naturalnych zjawisk i rzeczy, których uczeń doświadcza w kontakcie bezpośrednim, wynikać może z braku świadomości w niektórych kręgach nauczycielskich, a także z niskiego poziomu kompetencji w zakresie wykorzystania technologii informacyjno-komunikacyjnej (Huk 2019: 69). Duża część nauczycieli trwa przy wyuczonych, sprawdzalnych (kiedyś) metodach i nie stara się ich dostosować do teraźniejszych potrzeb i oczekiwań uczniów. Niejednokrotnie stosowany jest wciąż tradycyjny, linearny model nauczania. Należy jednak zaznaczyć, że coraz większa grupa nauczycieli stara się rozwijać kompetencje medialne 
oraz wykorzystywać media, np. tworząc kanały komunikacji - blogi, grupy na Facebooku czy czerpiąc wiedzę, inspiracje i wiadomości z sieci (Brzyszcz 2017: 33). Dostrzegają oni, że najnowsze technologie spełniają istotne zadania w prowadzeniu nauczania i upowszechnianiu edukacji. Ich realizacja jest możliwa jedynie w sytuacji, gdy zarówno uczący się, jak i nauczyciele potrafią się nimi posługiwać w odpowiednim stopniu.

W każdej z pięciu wyróżnionych przez Wacława Strykowskiego (2004: 35-37) grup kompetencji medialnych (kompetencje z zakresu teorii mediów, kompetencje z zakresu języka i komunikowania medialnego, kompetencje dotyczące odbioru komunikatów medialnych, kompetencje dotyczące korzystania $\mathrm{z}$ mediów oraz kompetencje dotyczące tworzenia komunikatów medialnych) można wyróżnić te najbardziej przydatne z punktu widzenia nauczyciela. Wśród kompetencji z zakresu teorii mediów istotna jest umiejętność dostrzegania i analizowania kierunków rozwoju mediów i ich konsekwencji oraz zdolność do identyfikacji i uzasadnienia wpływu technologii na różne aspekty życia człowieka. W przypadku kompetencji z zakresu języka i komunikowania medialnego ważna staje się umiejętność określenia znaczenia i celowości użycia środków wyrazowych (np. kolor, kształt, znak graficzny) oraz znajomość podstawowych technik komunikowania bezpośredniego i medialnego. W obszarze odbioru komunikatów medialnych uwagę zwrócić należy na znajomość mechanizmów psychologicznego oddziaływania mediów na odbiorcę, umiejętność wskazania płynących z mediów zagrożeń dla psychicznego i wychowawczego rozwoju człowieka, a także zdolność dostrzegania roli mediów w rozwijaniu osobowości, kształtowaniu postaw młodego człowieka i kreowaniu autorytetów. Nauczyciel kompetentny $\mathrm{w}$ zakresie korzystania $\mathrm{z}$ mediów postrzega je jako źródła wiedzy i narzędzia służące kształtowaniu umiejętności, zna metody i narzędzia wyszukiwania informacji w mediach, wykorzystuje różnorodne urządzenia i materiały medialne, potrafi kategoryzować, selekcjonować i wartościować znalezione informacje oraz wykorzystywać urządzenia medialne służące do zapisu, przetwarzania i udostępniania medialnych komunikatów. W zakresie tworzenia komunikatów medialnych największe dla nauczyciela znaczenie mają: umiejętność poprawnego wypowiadania się przed mikrofonem czy kamerą; zdolność do właściwej autoprezentacji; posiadanie wiedzy na 
temat warsztatu i procesu konstruowania przekazów; umiejętność samodzielnego opracowywania, realizowania i prowadzenia prezentacji multimedialnych z zastosowaniem materiałów i bodźców odpowiednich do możliwości percepcyjnych odbiorcy.

Ważnym obszarem wykorzystania komputera w edukacji jest też diagnoza i terapia pedagogiczna. Programy komputerowe z zakresu terapii pedagogicznej obejmują sferę percepcyjno-motoryczną, wzrokową, słuchową, intelektualną oraz emocjonalną, a dzięki atrakcyjnej formie zajęć prowadzonych $\mathrm{z}$ ich wykorzystaniem mogą się przyczynić do pobudzenia sfery emocjonalno-motywacyjnej dzieci czy eliminować lęk przed niepowodzeniami lub brakiem postępów w nauce. Komputer to także wiele możliwości kształcenia i rewalidacji osób mających problemy ze słuchem, wzrokiem oraz z trudnościami w rozwoju ruchowym czy umysłowym (Gajda 2010: 141).

Urządzenia najnowszej generacji budzą niepokój i wywołują dystans wśród nauczycieli, którzy nie zostali w wystarczającym stopniu zaznajomieni z dzisiejszymi technologiami. Nie chcą oni często porzucić znanych sobie narzędzi, by wykorzystać potencjał mediów cyfrowych. Wiąże się to także $\mathrm{z}$ obawą, że nowych technologii nie uda się okiełznać (Cyrek 2019: 291). Ostrożne czy wręcz niechętne nastawienie do wykorzystania cyfrowych mediów czy zdalnego nauczania można wyjaśnić nowością proponowanego rozwiązania dla części nauczycieli, niepewnością czy poczuciem zagrożenia. Założyć jednak trzeba, że nauczanie zdalne stanie się trwałym elementem rzeczywistości edukacyjnej (Łaszczyk 2005: 57).

Wielu nauczycieli z nowymi technologiami spotkało się dopiero w związku ze stawianymi im wymogami w środowisku zawodowym. Nawet jeśli dokonało się to w procesie edukacji formalnej, to edukacja medialna dopiero się rozwijała. Pozytywną motywację stanowić powinien jednak fakt, że satysfakcjonujące korzystanie $z$ nowych technologii oparte jest na podobnych zasobach intelektualnych, co satysfakcjonujące działanie w innych aspektach życia, a są to: dojrzałość, mądrość, krytycyzm, dobra komunikatywność, umiejętność budowania i podtrzymywania relacji międzyludzkich (Bierówka 2019: 257-260). Jako że praca nauczyciela wymaga umiejętności społecznych na wysokim poziomie, nauczanie $z$ wykorzystaniem nowych mediów oparte na podobnych fundamentach także powinno dać pozytywne rezultaty. 
W całym tym zagubieniu i chaosie $\mathrm{z}$ pomocą przychodzi Jacek Pyżalski (2020: 25-26), twierdząc, że w dotychczasowej, dobrze prowadzonej edukacji, relacje zawsze stanowiły podstawę. Warto więc podkreślić, że nic się tutaj nie zmieniło. Jest tylko trochę trudniej i w sytuacji, która wymusza konieczność nauczania zdalnego, mamy do czynienia $z$ większym ryzykiem utraty takich więzi. Konieczne staje się więc wypracowanie, poznanie i wdrożenie rozwiązań, które pozwolą nam relacje te budować i wzmacniać, bo bez mądrych działań w tym obszarze osiągnięcie efektów wartościowych edukacyjnie będzie trudne albo wręcz niemożliwe. Dopiero na tej bazie, jaką stanowią edukacyjne relacje międzyludzkie, możliwe jest skuteczne prowadzenie zdalnej dydaktyki.

\section{Zakończenie}

Zadaniem nauczyciela XXI wieku staje się pokazanie uczniowi, jak się uczyć, jak dotrzeć do wiarygodnych i rzetelnych informacji oraz pomoc $\mathrm{w}$ przygotowaniu do funkcjonowania $\mathrm{w}$ nowoczesnym społeczeństwie, w którym przyjdzie mu w przyszłości żyć i pracować (Kołodziejczyk, Polak 2011: 53-55). Współczesne młode pokolenie to ludzie, którzy być może w przyszłości będą wykonywać zawody obecnie jeszcze nieznane, a przyszłość ta coraz bardziej będzie się opierać na nowych technologiach (Królikiewicz, Pulak 2020: 37). Misją nauczyciela jest więc dzisiaj przygotowanie uczniów do roli kreatorów wiedzy - wyposażenie ich w umiejętność samodzielnego jej budowania z pozyskiwanych, w dużej części z Internetu, informacji. Łatwość dostępu do informacji nie jest bowiem równoznaczna z pozyskiwaniem wiedzy, a każde z mediów wymaga przygotowania i wysiłku ze strony użytkownika, bo im użytkownik jest intelektualnie silniejszy, tym większe dla swojego rozwoju korzyści z wykorzystywania cyfrowych technologii odniesie (Morbitzer 2018: 16-17). Wśród atutów podkreślić należy między innymi: większą atrakcyjność zajęć; pobudzanie kreatywnego myślenia; wzrost motywacji i większe zaangażowanie niektórych, dotychczas biernych uczniów; rozwój kompetencji cyfrowych (uznawanych obecnie za kluczowe) zarówno nauczycieli, jak i uczniów; wymianę doświadczeń, wzajemne uczenie się; integrację i współpracę nauczycieli i uczniów; możliwość dostosowania do indywidualnych potrzeb uczniów (również 
tych z deficytami czy niepełnosprawnościami); pozytywne postrzeganie przez uczniów nauczyciela biegłego w stosowaniu narzędzi cyfrowych; nauczanie interdyscyplinarne. Trzeba pamiętać także o pułapkach i niebezpieczeństwach takich jak: bezrefleksyjne korzystanie z Internetu i informacji, intelektualne rozleniwienie, niewłaściwe treści czy uzależnienia, jednak w mądrym wykorzystaniu cyfrowych narzędzi, prowadzonym przez przygotowanych do tego nauczycieli, przeważać będą korzyści. Technologia ma wspomagać nauczyciela, a nie go zastąpić. Ważne jest więc, by nasycenie technologiami równoznaczne było z jakością procesu edukacyjnego, którego nauczyciel jest ogniwem nieodzownym.

W niniejszym artykule zwrócono uwagę na wymagania i wyzwania stojące przed nauczycielami w zakresie stosowania nowych narzędzi w procesie edukacyjnym, by wskazać, jak ważne są to obecnie kompetencje i, być może, przekonać tych, którzy mają wątpliwości, że są to umiejętności w dzisiejszym świecie niezbędne i wymagające nie tylko technicznej (czy technologicznej) sprawności, ale i refleksyjnego podejścia.

Myśl Umberta Eco niech będzie podsumowaniem podjętych rozważań. Ów wybitny filozof i medioznawca w swoim ostatnim dziele stwierdza, że „dobra lekcja to taka, w trakcie której nawiązuje się dialog, konfrontuje się opinie i dyskutuje nad tym, czego uczy szkoła, a czego dowiadujemy się z zewnątrz" (Eco 2017: 105). I takich lekcji wszystkim nauczycielom pozostaje życzyć.

\section{Bibliografia}

Banasik A. (2017). Nowe media wszkole podstawowej, „Lubelski Rocznik Pedagogiczny", t. 36, nr 1, s. 223-234.

Baron-Polańczyk E. (2012). Model kompetencji informacyjnych w zakresie wykorzystania ICT, [w:] Nowe media w edukacji, red. T. Lewowicki, B. Siemieniecki, Toruń: Wydawnictwo Adam Marszałek, s. 166-183.

Bauman Z. (2011). 44 listy ze śrwiata ptynnej nowoczesności, przeł. T. Kunz, Kraków: Wydawnictwo Literackie.

Bierówka J. (2019). Rodzice cyfrowych tubylców - cyfrowi imigranci w środowisku nowych mediórw, [w:] Wspótczesny świat dziecka. Media i konsumpcja, red. M. Bogunia-Borowska, Kraków: Wydawnictwo Uniwersytetu Jagiellońskiego, s. 253-269. 
Brzyszcz E. (2017). Cyfrowi tubylcy i cyfrowi imigranci we wspótczesnej szkole: kompetencje medialne nauczycieli - teoria, rozwój, implikacje, „Rynek Społeczeństwo - Kultura”, nr 1(22), s. 32-35.

Cyrek B. (2019). Internet w szkole - szkota w Internecie: jak wirtualny dziennik wptynąt na relacje między uczniem, nauczycielem i rodzicem, [w:] Wspótczesny swiat dziecka. Media i konsumpcja, red. M. Bogunia-Borowska, Kraków: Wydawnictwo Uniwersytetu Jagiellońskiego, s. 289-297.

Eco U. (2017). Pape Satàn aleppe. Kroniki plynnego myślenia, przeł. A. Bruś, Poznań: Dom Wydawniczy Rebis.

Gajda J. (2010). Media w edukacji, Kraków: Oficyna Wydawnicza „Impuls”.

Hankała A. (2005). Interakcje pedagogiczne w nauczaniu na odlegtośc z perspektywy psychologii, [w:] Pedagogika a środki informatyczne i media, red. M. Tanaś, Kraków: Oficyna Wydawnicza „Impuls”, s. 17-29.

Harari Y.N. (2015). Homo deus. Krótka historia ludzkości, przeł. M. Romanek, Kraków: Wydawnictwo Literackie.

Holtkamp J. (2011). Co ogtupia nasze dzieci? Nowe media jako wyzwanie dla rodziców, przeł. L. Mohort-Kopaczyńska, Kraków: Wydawnictwo Salwator.

Huk T. (2019). Uczniowskie korzyści z funkcjonowania w rzeczywistości szkolnego pogranicza między światami mediów online i offline. Kraków: Oficyna Wydawnicza „Impuls”.

Juszczyk-Rygałło J. (2015). Nowe media a ksztatt wczesnej edukacji, [w:] Człowiek - Technologia - Media. Konteksty kulturowe i psychologiczne, red. A. Ogonowska, G. Ptaszek, Kraków: Oficyna Wydawnicza „Impuls", s. 51-61.

Kobyłecka E. (2010). Kwalifikacje i kompetencje wspótczesnego nauczyciela-wychowawcy, [w:] Jakośc życia i jakość szkoty. Wprowadzenie w zagadnienia jakości i efektywności pracy szkoty, red. I. Nowosad, I. Mortag, J. Ondráková, Zielona Góra: Oficyna Wydawnicza Uniwersytetu Zielonogórskiego, s. 105-120.

Kołodziejczyk W., Polak M. (2011). Jak zmieniać się będzie edukacja. Wyzwania dla polskiej szkoty i ucznia, Warszawa: Instytut Obywatelski.

Królikiewicz R., Pulak I. (2020). Możliwości wspierania edukacji domowej nowoczesnymi technologiami informacyjno-komunikacyjnymi, „Edukacja Elementarna w Teorii i Praktyce”, t. 15, nr 1(55), s. 23-38.

Krzyżanowska A. (2018). Efektywna edukacja. W poszukiwaniu balansu między technologiq, kulturq i naturq, [w:] Kompetencje przysztości, red. S.M. Kwiatkowski, Warszawa: Fundacja Rozwoju Systemu Edukacji, Seria Naukowa, t. 3, s. 206-226.

Łaszczyk J. (2005). Zadania ksztatcenia i edukacja zdalna, [w:] Pedagogika a środki informatyczne i media, red. M. Tanaś, Kraków: Oficyna Wydawnicza „Impuls”, s. 55-60.

Mead M. (2000). Kultura i tożsamość. Studium dystansu międzypokoleniowego, przeł. J. Hołówka, Warszawa: Wydawnictwo Naukowe PWN. 
Mischke J. (2005). Dylematy wspótczesnej edukacji: nauczanie tradycyjne czy zdalne?, [w:] Pedagogika a środki informatyczne i media, red. M. Tanaś, Kraków: Oficyna Wydawnicza „Impuls”, s. 45-54.

Morbitzer J. (2011). O nowej interpretacji niektórych pojęć pedagogicznych w dobie technologii informacyjnej, [w:] Edukacja jutra w kontekście wyzwań wspótczesności, red. K. Denek, A. Kamińska, W. Kojs, P. Oleśniewicz, Sosnowiec: Oficyna Wydawnicza „Humanitas”, s. 26-33.

Morbitzer J. (2012). O istocie medialności mtodego pokolenia, „Neoidagmata”, nr 33/34, s. 131-153.

Morbitzer J. (2018). O racjonalnym wykorzystaniu Internetu w edukacji, „Interdyscyplinarne Konteksty Pedagogiki Specjalnej”, nr 23, s. 13-28.

Muchacki M. (2016). Internet jako śodowisko edukacyjnego wspierania rozwoju zawodowego nauczycieli, [w:] Edukacja w zglobalizowanym świecie, red. V. Tanaś, W. Welskop, Łódź: Wydawnictwo Naukowe Wyższej Szkoły Biznesu i Nauk o Zdrowiu, s. 432-437.

Myrdzik B. (2015). Przestrzeń edukacyjna jako „wędrujące pojęcie”, [w:] Edukacja a nowe media, red. M. Latoch-Zielińska, I. Morawska, M. Potent-Ambroziewicz, Lublin: Wydawnictwo Uniwersytetu Marii Curie-Skłodowskiej, s. 13-23.

Popławska A., Aniskievich T. (2017). Wyzwania cyberprzestrzeni a wybrane kompetencje nauczycieli i uczniów, „Rocznik Lubuski”, t. 43, cz. 1, s. $245-258$.

Plebańska M. (2020). Potencjat technologii cyfrowych, [w:] Edukacja w czasach pandemii wirusa COVID-19. Z dystansem o tym, co robimy obecnie jako nauczyciele, red. J. Pyżalski, Warszawa: EduAkcja, s. 37-42.

Prensky M. (2001). Digital Natives, Digital Immigrants. Part 1, „On the Horizon", t. 9, nr 5, s. 1-6.

Pyżalski J. (2020). Co jest obecnie ważne, a co mniej w dziataniach szkót i nauczycieli?, [w:] Edukacja w czasach pandemii wirusa COVID-19. Z dystansem o tym, co robimy obecnie jako nauczyciele, red. J. Pyżalski, Warszawa: EduAkcja, s. 25-27.

Rozporządzenie Ministra Nauki i Szkolnictwa Wyższego z dnia 16 sierpnia 2018 r. w sprawie uzyskiwania stopni awansu zawodowego przez nauczycieli (Dz.U. 2018, poz. 1574).

Rozporządzenie Ministra Nauki i Szkolnictwa Wyższego z dnia 25 lipca 2019 r. w sprawie standardu kształcenia przygotowującego do wykonywania zawodu nauczyciela (Dz.U. 2019, poz. 1450).

Rygałło A. (2015). Czy szkota może być cyfrowa?, [w:] Cztowiek - Technologia - Media. Konteksty kulturowe i psychologiczne, red. A. Ogonowska, G. Ptaszek, Kraków: Oficyna Wydawnicza „Impuls”, s. 23-33.

Skrzydlewski W. (2004). Kompetencje medialne: edukacja, rynek pracy i funkcjonowanie spoteczne, [w:] Kompetencje medialne spoteczeństwa wiedzy, red. W. Strykowski, W. Skrzydlewski, Poznań: Wydawnictwo eMPi2, s. $41-46$. 
Spitzer M. (2013). Cyfrowa demencja, przeł. A. Lipiński, Słupsk: Wydawnictwo Dobra Literatura.

Strykowski W. (2004). Kompetencje medialne: pojecie, obszary, formy ksztatcenia, [w:] Kompetencje medialne spoteczeństwa wiedzy, red. W. Strykowski, W. Skrzydlewski, Poznań: Wydawnictwo eMPi2, s. 31-39.

Szot W. (2009). Kompetencje wspótczesnego nauczyciela orazjego funkcjonalność $w$ dobie przemian gospodarczych i procesu globalizacji, „Zeszyty Naukowe Małopolskiej Wyższej Szkoły Ekonomicznej w Tarnowie”, t. 1, nr 2(13), s. 301-322.

Ścibor J. (2020). Wstrzymaj siebie, rusz ucznia: e-nauczanie a e-twórczość, [w:] Edukacja w czasach pandemii wirusa COVID-19. Z dystansem o tym, co robimy obecnie jako nauczyciele, red. J. Pyżalski, Warszawa: EduAkcja, s. $59-63$.

Tanaś M. (2005). Dydaktyczny kontekst ksztatcenia na odlegtośc, [w:] Pedagogika a środki informatyczne i media, red. M. Tanaś, Kraków: Oficyna Wydawnicza „Impuls”, s. 31-44.

Tanaś M. (2015). Prolegomena do pedagogiki medialnej, [w:] CyberprzestrzeńCztowiek - Edukacja. Cyfrowa przestrzeń, red. M. Tanaś, S. Galanciak, Kraków: Oficyna Wydawnicza „Impuls”, s. 7-25.

Wenta K. (2007). Kwalifikacje nauczycieli edukacji medialnej i informatycznej, [w]: Pedagogika medialna. Podręcznik akademicki, t. 2, red. B. Siemieniecki, Warszawa: Wydawnictwo Naukowe PWN, s. 211-218.

Włoch S. (2010). Edukacja jaka? - szansa czy zagrożeniem rozwoju osobowośi ucznia, [w:] Edukacja jutra - Edukacja w spoteczeństwie wiedzy, red. K. Denek, A. Kamińska, W. Kojs, P. Oleśniewicz, Sosnowiec: Oficyna Wydawnicza „Humanitas”, s. 79-94.

Wronka S. (2018), Nowoczesne technologie w nauczaniu przedmiotów ścistych, [w:] Kompetencje przysztości, red. S.M. Kwiatkowski, Warszawa: Fundacja Rozwoju Systemu Edukacji, Seria Naukowa, t. 3, s. 335-347.

Zadworna-Cieślak M., Zbonikowski A. (2016). Stres $i$ wypalenie w zawodzie nauczyciela - charakterystyka zjawisk i cele wspótczesnej profilaktyki, [w:] Edukacja w zglobalizowanym świecie, red. V. Tanaś, W. Welskop, Łódź: Wydawnictwo Naukowe Wyższej Szkoły Biznesu i Nauk o Zdrowiu, s. $438-449$.

\section{Netografia}

Centrum Cyfrowe (2020). Edukacja zdalna w czasie pandemii. Raport z badań, https://centrumcyfrowe.pl/edukacja-zdalna/ [dostęp: 25.06.2020].

Librus (2020). Raport 2. Jak zmienito sie nauczanie zdalne?, https://portal. librus.pl/artykuly/raport-2-jak-zmienilo-sie-nauczanie-zdalne [dostęp: 26.06.2020]. 
Pacewicz A. (2020). Zdalna szkota? Jeszcze będziemy za nią tęsknić. Nauczyciel przestat być żandarmem, https://oko.press/zdalna-szkola-jeszcze-bedziemy-za-nia-tesknic/ [dostęp: 26.06.2020].

Polskie Towarzystwa Edukacji Medialnej, Fundacja Dbam o Mój Zasięg, Fundacja Orange (2020). Zdalne nauczanie a adaptacja do warunkórw spotecznych w czasie epidemii koronawirusa, https://glos.pl/badanie-zdalne-nauczanie-oczami-nauczycieli-uczniow-i-rodzicow-pogorszenie-relacji-i-samopoczucia-zmeczenie-cyfrowe [dostęp: 26.06.2020].

\section{ADRES DO KORESPONDENCJI}

Mgr Marzena Janta

Akademia Wyższa Szkoła Biznesu w Dąbrowie Górniczej

Doktorantka AWSB

e-mail: m.janta@valmot.eu 